\title{
Margit Bussmann* and Florian Ranft Distribution of Military Power and Prospects of Post-Conflict Peace
}

DOI 10.1515/peps-2016-0024

Previously published online October 8, 2016

\begin{abstract}
This study focuses on the distribution of military capabilities in the aftermath of civil wars and how it affects the recurrence of further fighting. Using survival analysis the empirical tests cover 48 post-conflict episodes in 33 countries and includes novel measurements on military capabilities. We find that peace is more likely to endure following military victories and peace agreements and when conflict parties are able to credibly signal their intentions to commit laying down arms.
\end{abstract}

Keywords: military capabilities, post-conflict stability, civil war recurrence

\section{Introduction}

The balance of power does not only explain the dynamics or the outcome of a war but can also have a significant impact on the post-conflict order. While not undisputed, there is an emerging consensus that peace after a civil war lasts longer if one of the conflict parties was able to defeat its opponent decisively (Quinn, Mason, and Gurses 2007; Toft 2010). A clear and decisive victory means that one conflict party has overwhelming fighting power and is able to defeat the enemy to an extent that it no longer has the military capacity to challenge the incumbent government. Civil wars that end in a military stalemate, on the other hand, are more difficult to resolve. In cases when the power between the belligerents is more equally balanced, conflict parties must find solutions for the incompatibilities at stake in order to stop fighting. In this process peace negotiations and agreements can help to overcome information asymmetries. Whether conflict parties are credibly committed to peace may be reflected by their willingness of power-sharing and military integration.

*Corresponding author: Margit Bussmann, University of Greifswald, Germany,

E-mail: margit.bussmann@uni-greifswald.de

Florian Ranft: University of Greifswald, Germany 
This study seeks to explain under which conditions post-conflict societies are more stable and which role military capabilities of warring parties play in securing peace. It will contribute to the body of literature that investigates the distribution of military power in particular by focusing on the distribution at the end of the war as well as during the post-conflict era. For the empirical analysis we draw on a new data set on post-civil war power and compromise collected by the Peace Research Institute in Frankfurt (PRIF). The time-series compilation contains information on the military balance and political compromises, including novel measurements on military resources and troops conflict parties have at their disposal and the territory that they control at the end, and after a civil war. The data set is unique in its scope, covering 48 civil wars between 1990 and 2009 with data on an annual basis for all variables, providing scholars with in-depth information on coding decisions for each case (Gromes and Ranft 2016).

\section{Military balance and the prospects of peace}

Our theoretical reasoning rests on two pillars that are derived from the bargaining model: information asymmetries and the commitment problem. As one of the most influential theories the bargaining model holds that fighting is costly and thus warring parties are better off by agreeing to a bargain ex ante, essentially avoiding costly fighting (Fearon 1995; Powell 2002; Reiter 2003). The failure to find a bargaining solution can help to explain civil wars at all stages: the onset, duration as well as recurrence of fighting (Walter 2009). The commitment problem and information asymmetries are major obstacles as to why warring parties find it extremely hard to successfully settle armed conflict and establish a stable postconflict order (Fearon 1995; Walter 1997).

Conflict parties prefer a negotiated settlement to a costly war under the assumption of complete information (Fearon 1995). However, they typically have incentives to keep information about their military capabilities private and misrepresent them during different conflict stages. Focusing on the termination of civil wars the literature identifies four types: military victories (government or rebel), peace agreements, ceasefires or unclear circumstances (Kreutz 2010). Wagner (1993) provides an explanation of why civil wars are less likely to recur after military victory. In a nutshell he argues that a decisive victory severely damages the enemies' organizational structures and collective goal. They can comprehensively reveal private information about the opponent reducing or even making information asymmetries and uncertainties obsolete.

In contrast, if warring parties seek to find negotiated settlement information asymmetries are more likely to prevail. During the negotiation process conflict 
parties have incentives to misrepresent information. In particular, rebel factions may attempt to keep information about their military capabilities private because if governments renege on the deal they can be used against them in later conflict stages. Another reason is that insurgents might try to appear more powerful than they actually are in negotiations, in order to reach a favorable deal (Walter 1999). Such patterns of misrepresentation are more likely to persist after negotiated settlements than military victories because it is less obvious which side has the advantage on the battlefield. Thus, we expect that post-conflict peace is more likely to endure following decisive military victories, whereas peace is less likely to last if both conflict parties have still the capacity to continue fighting.

A second major obstacle for finding a bargaining solution is the commitment problem. The core argument is that incentives to renege on a peace agreement leave conflict parties in a vulnerable situation (Fearon 1995; Walter 2002, 2009). If neither conflict party was able to secure a military victory but instead ended up in a military stalemate they find themselves in a state of domestic anarchy (Walter 1997, 338). In this situation both camps have established separate "dual" security apparatuses where no central authority ensures public order through police, security or judicial services. Nevertheless, cooperation is indispensable because the provision of security for citizens requires the resolution of anarchy and the dissolution of dual sovereignty (Quinn, Mason, and Gurses 2007).

One way to overcome this commitment problem is military power-sharing where government and rebel forces are integrated into national armed forces or police services. This measure is widely understood as a signal by the government to provide the opposition with security guarantees leaving a share of troops under their command (Hoddie and Hartzell 2003). In case of government defection during the most vulnerable and critical stage of demobilization rebels will not be faced with immediate annihilation but retain some military capacities for self-defence. Thus, we expect peace to be more durable if some sort of military power-sharing arrangement is part of the bargaining deal.

\section{Research design}

The main objective of the statistical analysis is to explore to what extent post-conflict countries that experienced a civil war are likely to experience another one given certain values of a set of independent variables. The analyses focus on developments in the aftermath of a conflict. Our unit of observation is the rebel-government dyad in post-conflict years. Using the PRIF data (Gromes and Ranft 2016) the analysis covers all intra-state armed conflicts with 
at least 1000 fatalities over the entire conflict that terminated between 1990 and 2009 according to the UCDP Conflict Termination Dataset v.2010-1, 1946-2009 (Kreutz 2010). Overall the data contains 48 post-conflict episodes in 33 countries of which 17 experienced the recurrence of armed violence (again with at least 1000 fatalities) of warring factions until 2012 when our analysis ends. For the statistical analysis limited dependent variable models are employed (Hosmer and Lemeshow 1999, 2000). The choice of these models best reflects the data structure where the post-conflict episodes as the unit of analysis are recorded as a series of time.

The risk of civil war recurrence is measured by the dependent variable indicating whether civil war broke out again in a given post-conflict year. The coding relies on PRIF data, which is based on information by the UCDP/PRIO Armed Conflict Dataset v.4-2015 (Gleditsch et al. 2002). To assess whether one side decisively won the armed conflict we include information from PRIF. They took data from the UCDP Conflict Termination Dataset v.2010-1 (Kreutz 2010) as a starting point and additionally considered case-specific literature and expert validation for each coding decision. We distinguished between civil wars that were terminated by peace agreement and military victories. For instance, the civil war in Angola between the People's Movement for the Liberation of Angola against the National Union for the Total Independence of Angola (UNITA) was terminated by a peace agreement in 2002 where incompatibilities were regulated by concessions rather than further fighting. In comparison, the civil war in Sri Lanka where the central government fought various rebel groups, including the Liberation Tigers of Tamil Eelam, was terminated by a decisive military victory by government troops. Drawing on the PRIF data we also included dummy variables capturing whether one or both sides were able to continue armed conflict in more than a sporadic manner during the last weeks of the conflict. We added a variable to capture whether rebels participated in military power-sharing (based on the PRIF data). It takes the value of one if both parties participate substantially (i.e. with at least 3000 persons or 20\%) in the state military or police forces.

Our baseline model (model 1) draws upon a number of variables that have been identified in previous studies to explain the recurrence of civil wars, namely opportunity costs for rebellion (GDP per capita, based on purchasing power parity 2011 dollar prices), ethnic conflicts, conflict intensity and duration of previous fighting (Fortna 2004, 2008; Mason et al. 2011; Quinn, Mason, and Gurses 2007; Toft 2010; Wucherpfennig 2011). As the GDP per capita variable violates the proportional hazard assumption we specify the model with an interaction of GDP per capita with the logged time, a procedure which is advised by Box-Steffensmeier and Jones (2004). 


\section{Empirical findings}

The results of the control variables in Table 1 largely follow our expectations and support previous studies. The risk that peace will fail is smaller in economically more developed countries, whereas conflicts that are related to ethnic issues are more likely to break out again. Both higher degrees of conflict intensity and duration indicate a greater risk of peace failure but are statistically insignificant.

At first, we focus on the distribution of power at the time when the war ends (model 2). Our results on the type of conflict outcome confirm previous findings (Mason et al. 2011, Toft 2010). Armed conflicts that end in a decisive victory are

Table 1: Determinants of civil war recurrence.

\begin{tabular}{|c|c|c|c|c|}
\hline & (Model 1) & (Model 2) & (Model 3) & (Model 4) \\
\hline \multirow[t]{2}{*}{ GDP per capita (ln) } & $0.547^{\star}$ & $0.503^{*}$ & $0.425^{\star \star}$ & $0.507^{\star \star}$ \\
\hline & $(0.185)$ & $(0.177)$ & $(0.181)$ & $(0.175)$ \\
\hline \multirow[t]{2}{*}{ GDP per capita $(\ln )^{\star} \ln (\mathrm{t})$} & 1.026 & 1.028 & 1.041 & 1.027 \\
\hline & $(0.022)$ & $(0.023)$ & $(0.027)$ & $(0.023)$ \\
\hline \multirow[t]{2}{*}{ Civil war duration (In) } & 1.128 & 1.203 & 1.103 & 1.214 \\
\hline & $(0.339)$ & $(0.487)$ & $(0.371)$ & $(0.555)$ \\
\hline \multirow[t]{2}{*}{ Civil war fatalities (In) } & 1.140 & 1.130 & 1.019 & 1.122 \\
\hline & $(0.158)$ & $(0.177)$ & $(0.156)$ & $(0.217)$ \\
\hline \multirow[t]{2}{*}{ Ethnic conflict } & $6.107^{\star \star}$ & 3.952 & 3.565 & 3.967 \\
\hline & $(4.965)$ & $(3.417)$ & (3.083) & (3.449) \\
\hline \multirow[t]{2}{*}{ Peace agreement } & & $0.311^{*}$ & 0.544 & $0.309 *$ \\
\hline & & $(0.206)$ & $(0.389)$ & $(0.214)$ \\
\hline \multirow[t]{2}{*}{ Victory } & & $0.338^{*}$ & $0.201^{\star \star}$ & 0.325 \\
\hline & & $(0.198)$ & $(0.144)$ & $(0.262)$ \\
\hline \multirow[t]{2}{*}{ Continued fighting power } & & & $3.634^{\star \star}$ & \\
\hline & & & $(2.373)$ & \\
\hline \multirow[t]{2}{*}{ Both in national military and police } & & & & 1.091 \\
\hline & & & & $(0.957)$ \\
\hline Observations & 553 & 553 & 553 & 553 \\
\hline Subjects & 48 & 48 & 48 & 48 \\
\hline Number of Failures & 17 & 17 & 17 & 17 \\
\hline AIC & 120.866 & 120.400 & 119.782 & 122.386 \\
\hline $\mathrm{BIC}$ & 142.443 & 150.608 & 154.305 & 156.909 \\
\hline Log likelihood & -55.433 & -53.200 & -51.891 & -53.193 \\
\hline
\end{tabular}

Hazard ratios and robust standard errors in parentheses are reported, clustered on civil wars; ${ }^{*} \mathrm{p}<0.1,{ }^{* *} \mathrm{p}<0.05$. 
less likely to break out again decreasing the risk of another civil war by nearly 70 per cent, regardless of whether we control for government forces or the rebel groups carrying a decisive victory. Our analyses also confirm that conflicts that terminate with a peace agreement are less likely to experience a renewed outbreak as well, a statistically significant result. We also tested the effect of conflict termination on civil war recurrence using the UCDP data by Kreutz (2010). The tests confirm the general finding that a victory provides for a longer lasting peace and the variable is highly significant.

In further tests in model 3, we also find as expected that peace is more likely to fail if both conflict parties have continuing fighting power. The hazard ratio is significant at $\mathrm{p}<0.05$. Sustainable peace is more difficult if sufficient military capabilities are still available to both conflict parties to continue the war in more than just a sporadic manner. Thus our tests confirm that peace is more stable if one party is significantly stronger and able to defeat the other. Figure 1 depicts the survival function where we see that the probability of peace survival drops quickly and substantively if either party has troops that would allow them to continue fighting in more than a sporadic manner.

In model 4 we assess the distribution of military capabilities in the aftermath of conflict termination. A substantial participation of both conflict parties in the national military is not related to a more stable peace; instead the hazard ratio indicates that the risk of peace failure rises, although the result is not statistically

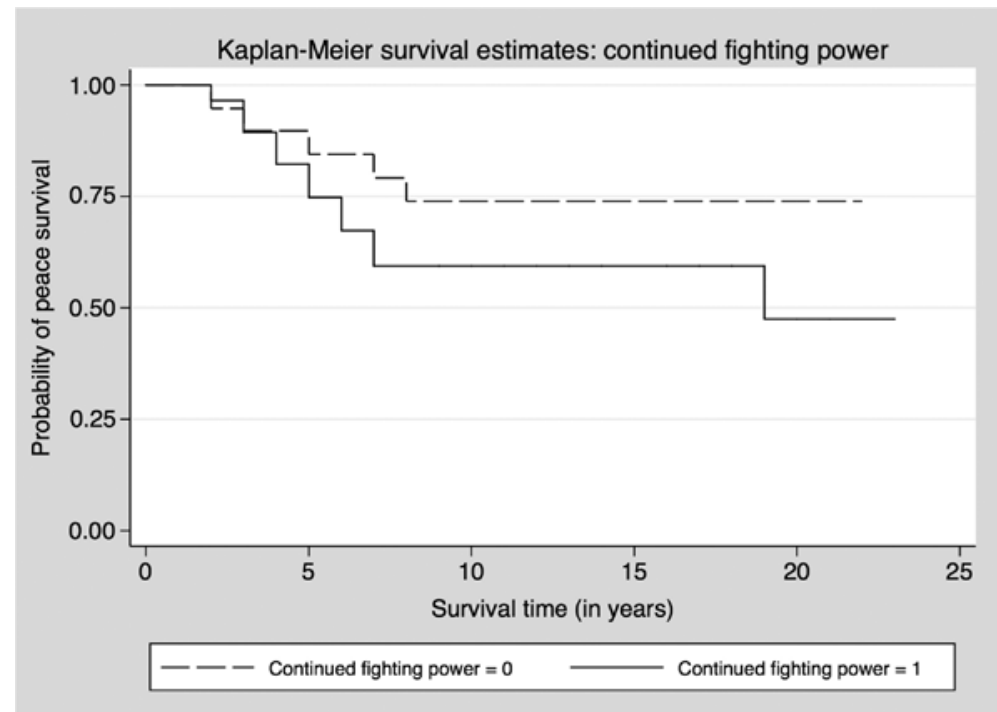

Figure 1: Kaplan-Meier survival estimates: continued fighting power. 
significant. This finding does not confirm previous results on the peace-enhancing effect of military-power sharing which might be due to the different samples used in the analyses and/or because of different variables used to assess military power-sharing (Jarstad and Nilsson 2008).

\section{Conclusion}

The recurrence of civil wars depends partly on how the war ended and how the conflict parties were able to integrate their forces. We assessed the distribution of military power at the time a civil war ends and its consequences for the duration of peace. Our results support previous findings that peace is more stable after a decisive victory and much less likely to last if military capacity is more balanced, or at least if both parties have enough capacity to continue fighting. Not just military victory but also a peace agreement makes the failure of peace less likely. These findings strongly support what others have concluded before, that conflicts ending for unclear reasons or simply level out are more likely to re-emerge.

To a certain extent this is good news for policymakers and experts in the field. The case of Colombia might be instructive in this context. The long and difficult peace negotiations between the Colombian government and the Revolutionary Armed Forces of Colombia which led to the conclusion of a comprehensive peace agreement in August 2016 might pay off in the long run. Peace agreements can help to reduce information asymmetries on the power distribution between both sides. Also, the FARC's military position has weakened in recent years shifting the military balance towards government forces, which might also contribute to a successful implementation.

Funding: German Research Foundation, (Grant/Award Number: “BU 2289/3-1/2”).

\section{References}

Box-Steffensmeier, J.M., Jones, B.S., (2004), Event History Modeling: A Guide for Social Scientists, Cambridge University Press, Cambridge.

Fearon, J.D., (1995), Rationalist Explanations for War, International Organization vol. 49, no. 3, pp. 379-414.

Fortna, V.P., (2004), Does Peacekeeping Keep Peace? International Intervention and the Duration of Peace after Civil War, International Studies Quarterly, vol. 48, no. 2, pp. 269-292. 
Fortna, V.P., (2008), Does Peacekeeping Work? Shaping Belligerents' Choices after Civil War, Princeton University Press, Princeton.

Gleditsch, N.P., Wallensteeen, P., Eriksson, M., Sollenberg, M., Strand, H., (2002), Armed Conflict 1946-2001: A New Dataset, Journal of Peace Research, vol. 39, no. 5, pp. 615-637.

Gromes, T., Ranft, F., (2016), The Dataset on Post-Civil War Power and Compromise, 1990-2012, Unpublished Manuscript, Peace Research Institut Frankfurt/University of Greifswald.

Hoddie, M., Hartzell, C., (2003), Civil War Settlements and the Implementation of Military Power-Sharing Arrangements, Journal of Peace Research, vol. 40, no. 3, pp. 303-320.

Hosmer, D.W., Lemeshow, S., (1999), Applied Survival Analysis, Wiley-Interscience, New York.

Hosmer, D.W., Lemeshow, S., (2000), Applied Logistic Regression, 2nd ed, Wiley-Interscience, New York.

Jarstad, A.K., Nilsson, D., (2008), From Words to Deeds: The Implementation of Power-Sharing Pacts in Peace Accords, Conflict Management and Peace Science, vol. 25, no. 3, pp. 206-223.

Kreutz, J., (2010), How and When Armed Conflicts End: Introducing the UCDP Conflict Termination Dataset, Journal of Peace Research, vol. 47, no. 2, pp. 243-250.

Mason, T.D., Gurses, M., Brandt, P.T., Quinn., J.M., (2011), When Civil Wars Recur: Conditions for Durable Peace after Civil Wars, International Studies Perspectives, vol. 12, no. 2, pp. 171-189.

Powell, R., (2002), Bargaing Theory and International Conflict, Annual Review of Political Science, vol. 5, pp. 1-30.

Quinn, J.M., Mason, T.D., Gurses, M., (2007), Sustaining the Peace: Determinants of Civil War Recurrence, International Interactions, vol. 33, no. 2, pp. 167-193.

Reiter, D., (2003), Exploring the Bargaining Model of War, Perspective on Politics, vol. 1, no. 1, pp. 27-43.

Toft, M.D., (2010), Ending Civil Wars: A Case for Rebel Victory? International Security, vol. 34, no. 4, pp. 7-36.

Wagner, R.H., (1993), The Causes of Peace, in Licklider, R., (ed.), Stopping the Killing: How Civil Wars End, New York University Press, New York, pp. 235-268.

Walter, B.F., (1997), The Critical Barrier to Civil War Settlement, International Organization, vol. 51, no. 3, pp. 335-364.

Walter, B.F., (1999), Designing Transitions from Civil War: Demobilization, Democratization, and Commitments to Peace, International Security, vol. 24, no. 1, pp. 127-155.

Walter, B.F., (2002), Commitment to Peace: The Successful Settlement of Civil Wars, Princeton University Press, Princeton.

Walter, B.F., (2009), Bargaining Failures and Civil War, Annual Review of Political Science, vol. 12, no. 1, 243-261.

Wucherpfennig, J., (2011), Endogenizing Power-Sharing After Ethnonationalist Civil War, in SGIR 7th Pan-European International Relations Conference, Stockholm.

Article note: Submitted as part of the proceedings of the 16th Jan Tinbergen European Peace Science Conference. Authors are listed in alphabetical order. 